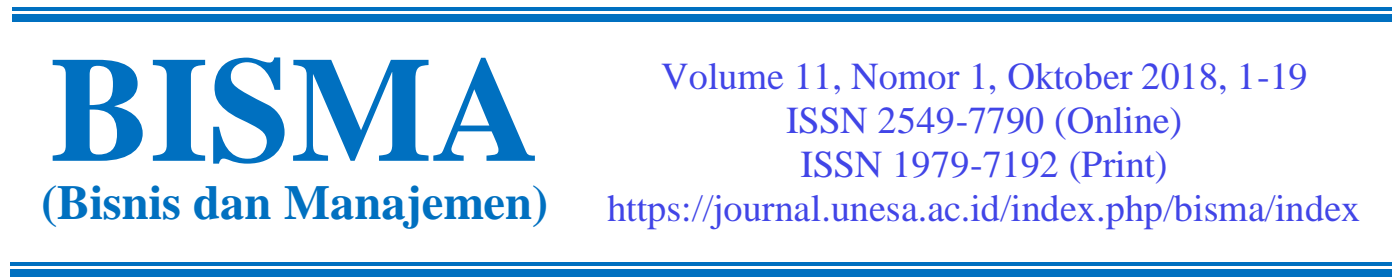

\title{
Pemberdayaan Ekonomi Perempuan melalui Usaha Penjualan Tabaro Dange
}

\author{
Rika Suprapty ${ }^{1}$ \\ STIE Panca Bhakti Palu ${ }^{1}$ \\ Email korespondesi: rikasu.hidar@gmail.com
}

\begin{abstract}
This study aims to find out how the method of economic empowerment of women through the sale of Tabaro Dange along the Palu Culinary Coast and how the strategy of women's economic empowerment through the sale of Tabaro Dange along the Palu Bay Culinary Area. This research uses qualitative or naturalistic approach with constructive paradigm. The research was conducted in the area along the bay coast of Palu City (Taman Ria, Cumi-Cumi road, and Cut Meutia road). Data collection techniques used in this study are interviews, observation and documentation. The result of the research shows that female economic empowerment method that can be applied through selling Tabaro Dange along Palu Bay Beach Culinary Area is a combination of PLA empowerment method (sharing and discussion about women economic empowerment through selling tabaro dange) and face to face, where this method is considered most adapted to the condition of the informant. This method is also known as the method of "learning by doing" or learning while working, so the implementation in the field of researchers do sharing and discussion while the informant serves the sales of tabaro dange so it is more efficient and effective and does not interfere with the activity of the informant. The women empowerment strategy applied to the selling business of tabaro dange conducted by the researcher is to arrange the data collection instrument; building understanding, commitment to encourage self-reliance of individuals, families and communities and preparing information systems, developing systems of analysis, intervention, monitoring and evaluation of individual, family and community empowerment.
\end{abstract}

Keywords: tabaro dange; women economic empowerment

Received: 29 Juli 2018

Reviewed: 20 Agustus 2018

Accepted: 15 September 2018

Published: 31 Oktober 2018

\section{PENDAHULUAN}

Pemberdayaan ekonomi rakyat dan kemiskinan adalah masalah pokok dan isu sentral pembangunan ekonomi dan sosial yang pada saat ini hingga beberapa tahun mendatang masih tetap relevan untuk terus dikaji di Indonesia. Pemberdayaan merupakan bentuk pendampingan yang dilakukan agar ekonomi 
rakyat mendapat bantuan pelayanan dalam hal pengetahuan dan keterampilan. Indikator mutu program pemberdayaan adalah terjadinya perubahan perilaku, peningkatan penghasilan, bertambahnya wawasan dan keilmuan serta keterampilan (skill) masyarakat. Pada akhirnya terwujud kemandirian (empowerment) sehingga fakir miskin terlepas dari kemiskinan dan ketergantungan. Bagi seorang pelaku perubahan, hal yang dilakukan terhadap individu, keluarga, kelompok atau komunitas adalah upaya memberdayakan dari keadaan tidak/kurang berdaya menjadi mempunyai daya guna mencapai kehidupan yang lebih baik.

Permasalahan yang dialami oleh masyarakat miskin menunjukkan bahwa kemiskinan bersumber dari ketidakberdayaan dan ketidakmampuan masyarakat dalam memenuhi hak-hak dasar mereka sebagai masyarakat miskin. Berbagai program penanggulangan kemiskinan dan pemberdayaan masyarakat yang telah diupayakan baik oleh pemerintah pusat, pemerintah daerah, maupun oleh organisasi non pemerintah antara lain: Program Jaring Pengaman Sosial (JPS), Program Subsidi Bahan Bakar Mentah (BBM), Program Beras Miskin (Raskin), Program Penanggulangan Kemiskinan Perkotaan (P2KP), Program Pengembangan Kecamatan (PPK), Program Prasarana Pendukung Desa Tertinggal (P3DT), Pemberdayaan Ekonomi Masyarakat Pesisir (PEMP), Kelompok Usaha Bersama (KUBE).

Salah satu upaya dalam mengurangi permasalahan ini dapat dilakukan dengan program pembagunan daerah. Tujuaan dari program ini tentunya menghilangkan kemiskinan dan menciptakan pemerataan laju pertumbuhan antar daerah yang disesuaikan dengan kemampuan masing-masing daerah. Di Indonesia, ekonomi kreatif mulai diakui memiliki peran yang sangat strategis dalam pembangunan ekonomi dan pembangunan bisnis. Ekonomi kreatif kini semakin diminati seiring perkembangan informasi dan teknologi. Ekonomi kreatif menjadi denyut nadi perekonomian yang memiliki hubungan erat dibidang budaya kewirausahaan yang akan diprediksi menjadi trend ekonomi dunia termasuk Indonesia yang akan ikut serta berperan aktif dalam Masyarakat Ekonomi Asia (MEA).

Kementrian Perdagangan Indonesia memberikan definisi tentang ekonomi kreatif sebagai industri yang berasal dari pemanfaatan kreatifitas, keterampilan serta bakat individu demi menciptakan kesejahteraan dengan menghasilkan dan mengeksploitasi daya kreasi dan cipta individutersebut (pariwisata.sumut.net, 2015). Lebih lanjut lagi Kementrian Perdagangan Indonesia mengklasifikasikan ekonomi kreatif menjadi 15 jenis, yaitu: advertising (periklanan), culinary (kuliner), showbiz (pertunjukkan), penerbitan dan percetakan, riset dan pengembangan, broadcasting (radio dan televisi), pelayanan komputer dan software, musik, video film dan fotografi, fashion (tatabusana), permainan interaktif, kerajinan (craft), kesenian (art), dan arsitektur. 
Mauled (2010:226-227) menyatakan bahwa membangun pencitraan melalui pengembangan ekonomi kreatif, dapat dilalui dengan berbagai cara, di antaranya adalah sebagai berikut. Pertama, melestarikan budaya lokal disertai penyesuaian terhadap perkembangan terbaru yang lebih modern agar menarik minat generasi muda dan pasar internasional. Kedua, melestarikan nilai-nilai budaya untuk meningkatkan reputasi Indonesia melalui proteksi warisan budaya. Ketiga, membangun perilaku dan semangat kreatif masyarakat berbasis budaya secara konsisten yang tercermin disegala dimensi sosial kemasyarakatan. Keempat, meningkatkan rasa memiliki budaya yang diwariskan oleh leluhur guna menumbuhkan perilaku kebanggaan atas budaya lokal dan kebanggaan memakai produk produksi dalam negeri yang dapat mendukung pencitraan negara. Kelima, meningkatkan konektivitas melalui kemajuan teknologi yang disinergikan dengan nilai-nilai simbolik suatu produk agar bisa membawa suatu negara yang berkarakter spesifik.

Kemajuan zaman menuntut masyarakat untuk lebih berkembang dan lebih kreatif dalam memenuhi kebutuhan mereka. Kreatif dalam mengembangkan skill dan memanfaatkan potensi yang telah ada dimiliki oleh masyarakat, salah satunya dengan menggalakkan spirit berwirausaha kepada seluruh lapisan masyarakat yang dapat digerakkan oleh kaum perempuan. Pemberdayaan perempuan merupakan kemampuan untuk membuat suatu keputusan dan memengaruhi hasil yang berguna bagi diri mereka sendiri dan keluarga. Ide utama pemberdayaan perempuan bermuara dari konsep kesetaraan gender. Kesetaraan gender merupakan sebuah kondisi di mana perempuan memperoleh keadilan dan kesempatan yang sama, dan gender tidak lagi menjadi dasar diskriminasi dan ketidakadilan di antara masyarakat. Pemberdayaan perempuan merupakan program peningkatan kualitas perempuan. Pemberdayaan perempuan yang terfokus pada tiga issue yaitu pemberdayaan perempuan melalui kegiatan ekonomi produktif dan kreatif, pemberdayaan perempuan melalui kegiatan kesehatan, dan pemberdayaan perempuan melalui kegiatan pendidikan Saat ini perempuan bisa dianggap sebagai salah satu roda penggerak ekonomi dengan membuka usaha atau menjalankan berbagai usaha ekonomi kreatif salah satunya dibidang bisnis kuliner tradisional.

Masyarakat Kota Palu memiliki penganan tradisional yang dibuat dari olahan sagu yang disebut dengan Tabaro Dange atau Jepa. Kudapan ini menjadi pilihan bagi masyarakat sekitar Kota Palu di waktu senggang atau yang mulai bosan dengan citarasa makanan cepat saji (fastfood), umumnya dijual pada waktu sore sampai malam hari. Ibu-ibu penjual Tabaro Dange di sepanjang Kawasan Kuliner Pantai Teluk Palu membuat penganan ini dengan cara tradisional serta masih mempertahankan kearifan lokal dalam mengolah penganan tersebut yaitu hanya menggunakan tungku dan juga tanah liat. Hal tersebut menciptakan daya tarik sendiri bagi pembeli ketika menyaksikan secara langsung proses 
pembuatannya. Pengolahan penganan ini secara tradisional juga dipercaya dapat menjaga kualitas rasa dari Tabaro Dange tersebut.

Pemberdayaan ekonomi perempuan melalui usaha penjualan Tabaro Dange merupakan bentuk ekonomi kreatif yang harus dikembangkan dan memprioritaskan ciri khas budaya kuliner masyarakat lokal kota Palu yang patut dilestarikan. Sehingga diharapkan akan diketahui metode pemberdayaan dan strategi pemberdayaan yang dapat meningkatkan kesejahteraan ekonomi ibu-ibu penjual Tabaro Dange karena selama ini penghasilan dari penjualan Tabaro Dange ini belum dapat meningkatkan perekonomian ibu-ibu penjual Tabaro Dange tersebut. Selain itu, lokasi penelitian yang sangat strategis dan mudah dijangkau untuk melakukan observasi penelitian merupakan alasan lain yang diambil oleh peneliti untuk meneliti usaha penjualan Tabaro Dange disepanjang Kawasan Kuliner Pantai Teluk Palu.

Penelitian sebelumnya telah banyak mengenai pemberdayaan ekonomi perempuan. Peneliti-peneliti terdahulu seperti Rohmah (2014); Thoha (2009); dan Bariyah (2012) lebih mengarah ke konsep pemberdayaan ekonomi syariah. Penelitian ini menggunakan pendekatan kualitatif atau naturalistic dengan paradigma konstruktifisme yang memandang manusia sebagai orang yang aktif menciptakan kehidupan sosialnya sendiri, tidak memandang individu yang statis dan terpaksa dalam bertindak. Adapun sifat penelitan ini adalah merupakan penelitian dekriptif analitis kritis, yaitu suatu penelitian yang berupaya untuk menggambarkan secara rinci fenomena sosial yang menjadi pokok permasalahan tanpa melakukan hipotesa dan perhitungan secara statistik. Berdasarkan latar belakang diatas maka dapat diidentifikasi permasalahan sebagai berikut. (1) Bagaimana metode pemberdayaan ekonomi perempuan melalui usaha penjualan Tabaro Dange di sepanjang Kawasan Kuliner Pantai Teluk Palu? (2) Bagaimana strategi pemberdayaan ekonomi perempuan melalui usaha penjualan Tabaro Dange di sepanjang Kawasan Kuliner Pantai Teluk Palu?

\section{Pemberdayaan Ekonomi}

Secara konseptual, pemberdayaan atau pemberkuasaan (empowerment) berasal dari kata power (kekuasan atau keberdayaan). Dalam hal ini Ife (2015) berpendapat bahwa pemberdayaan memuat elit kekuasaan dan kelompok lemah. Menurut Suharto (2010) pemberdayaan menunjuk pada kemampuan orang, khususnya kelompok rentan dan lemah sehingga mereka memiliki kekuatan atau kemampuan: (a) memenuhi kebutuhan dasarnya sehingga memiliki kebebasan (freedom), bebas dari kebodohan dan kesakitan; (b) menjangkau sumber-sumber produktif yang memungkinkan mereka dapat meningkatkan pendapatannya; dan (c) berpartisipasi dalam proses-proses pembangunan. Sulistiyani (2004:7) menjelaskan bahwa secara etimologis pemberdayaan berasal dari kata dasar daya yang berarti kekuatan atau kemampuan. Bertolak dari pengertian tersebut, pemberdayaan dimaknai sebagai proses untuk memperoleh daya, kekuatan atau 
kemampuan, dan atau pemberian daya, kekuatan atau kemampuan dari pihak yang memiliki daya kepada pihak yang kurang atau belum berdaya.

Berdasarkan penjelasan di atas dapat disimpulkan bahwa pemberdayaan adalah proses untuk memperoleh daya, kekuatan atau kemampuan, dan atau pemberian daya, kekuatan atau kemampuan dari pihak yang memiliki daya kepada pihak yang kurang atau belum berdaya. Dalam penelitian ini yang dimaksud pemberdayaan adalah pemberdayaan yang dilakukan terhadap perempuan penjual Tabaro Dange disepanjang Kawasan Pantai Teluk Palu. Pemberdayaan ekonomi adalah penguatan pemilikan faktor-faktor produksi, penguatan penguasaan distribusi dan pemasaran, penguatan masyarakat untuk mendapatkan gaji atau upah yang memadai dan penguatan masyarakat untuk memperoleh informasi, pengetahuan dan keterampilan yang harus dilakukan secara multi aspek, baik dari aspek masyarakatnya sendiri maupun aspek kebijakannya.

Ekonomi dapat diartikan sebagai upaya dalam mengelola rumah tangga. Tujuannya adalah untuk memenuhi kebutuhan hidup melalui 3 kegiatan utama yaitu: produksi, distribusi dan konsumsi. Produksi, distribusi dan konsumsi merupakan rangkaian kegiatan yang berlangsung secara terus menerus dan sering disebut sebagai proses yang berkesinambungan. Proses ini berjalan secara alamiah sejalan dengan perkembangan masyarakat dibidang sosial, ekonomi, budaya dan politik. Dengan demikian pemberdayaan ekonomi adalah kegiatan ekonomi yang dilakukan oleh masyarakat dengan swadaya mengelolah sumber daya apapun yang dapat dikuasainya, dan ditunjukan untuk memenuhi kebutuhan dasar dan keluarganya.

\section{Pemberdayaan Ekonomi Perempuan}

Pemberdayaan ekonomi perempuan yaitu upaya-upaya yang dilakukan dengan cara membuka lapangan kerja atau meningkatkan potensi, bakat dan kemampuan perempuan untuk membuka usaha kecil secara bertahap ditingkat manajerialnya (Rohmah:2014). Dalam hal peningkatan ekonomi perempuan di Indonesia khususnya di daerah pedesaan, perempuan memiliki keterbatasan dalam menjalankan aktivitasnya, keterbatasan tersebut seperti rendahnya pendidikan, keterampilan, sedikitnya kesempatan kerja, dan juga hambatan ideologis perempuan yang terkait rumah tangga. Selain itu, perempuan juga dihadapkan pada kendala tertentu yang dikenal dengan istilah tripple burden of women, yaitu perempuan harus melakukan fungsi reproduksi, produksi dan fungsi sosial secara bersamaan di masyarakat. Hal tersebut menyebabkan kesempatan perempuan untuk memanfaatkan peluang ekonomi yang ada menjadi sangat terbatas. Oleh karena itu program pemberdayaan bagi perempuan di bidang ekonomi sangat diperlukan karena pada dasarnya perempuan memiliki potensi yang luar biasa dalam perekonomian terutama dalam pengaturan ekonomi rumah tangga. Dorongan untuk keluar dari kemiskinan menuntut adanya peran aktif serta tanggung jawab dari seluruh anggota keluarga. Kenyataan ini menunjukkan 
bahwa perempuan memiliki peran yang cukup besar untuk membawa keluarganya keluar dari himpitan ekonomi, sebab selain bekerja pada sektor domestik (dalam rumah tangga) mereka bahkan dituntut pula untuk dapat berperan dalam sektor publik (di luar rumah).

\section{Metode Pemberdayaan Perempuan}

Kang dan Song dalam Mardikanto dan Soebiato (2013:197) menyimpulkan bahwa tidak ada satu pun metode yang selalu efektif untuk diterapkan dalam setiap kegiatan pemberdayaan masyarakat. Oleh karena itu, didalam setiap pelaksanaan pemberdayaan masyarakat, kita harus memahami dan mampu memilih metode pemberdayaan masyarakat yang paling tepat dan yang paling sesuai dengan kondisi penerima manfaat dari pemberdayaan tersebut. Sehingga tujuan dari pemberdayaan masyarakat yang dimaksud dapat tercapai. Menurut Mardikanto dan Soebiato (2013:198) beragam metode pemberdayaan masyarakat yang dapat digunakan adalah sebagai berikut: Tatap muka, percakapan tak langsung, demonstrasi, barang cetakan, media masa, dan kampanye.

Selain metode-metode di atas, perkembangan terakhir tentang metode pemberdayaan masyarakat yang dapat diterapkan yaitu suatu pendekatan partisipatif di antaranya sebagai berikut. (a) RRA (Rapid Rural Appraisal), suatu teknik penilaian dari "orang luar" yang menggabungkan beberapa tekhnik yaitu: review/telaah data sekunder; observasi/pengamatan lapangan secara langsung; wawancara dengan informan kunci dan lokakarya; pemetaan dan pembuatan diagram/grafik; studi kasus, sejarah local dan biografi; kecenderungankecenderungan; pembuatan kuesioner sederhana yang singkat; serta pembuatan laporan lapangan secara cepat. Metode pemberdayaan ini cocok diterapkan dalam bidang pertanian. (b) PRA (Participatory Rapid Appraisal) atau Penilaian Desa secara Partisipatif, merupakan metode penyempurnaan dari RRA dimana perbedaannya adalah RRA dilakukan oleh "orang luar" sedangkan PRA dilakukan oleh sekelompok tim yang terdiri dari "orang dalam" seperti semua pemangku kepentingan kegiatan dengan difasilitasi oleh orang luar yang lebih berfungsi sebagai narasumber atau fasilitator. (c) FGD (Focus Group Discussion) atau Diskusi Kelompok yang Terarah, merupakan tehknik wawancara pada penelitian kualitatif yang berupa in dept interview kepada sekelompok informan secara terfokus. Perkembangan selanjutnya, FGD lebih banyak diterapkan dalam kegiatan perencanaan dan evaluasi suatu program pemberdayaan. Pelaksanaan FGD dirancang sebagai diskusi kelompok terarah yang melibatkan semua pemangku kepentingan suatu program pemberdayaan, melalui diskusi yang partisipatif dengan dipandu atau difasilitasi oleh seorang pemandu dan kadang mengundang narasumber. (d) PLA (Participatory Learning and Action) atau Proses Belajar dan Praktik secara Partisipatif, merupakan bentuk baru dari metode pemberdayaan masyarakat yang dahulu dikenal sebagai "learning by doing" atau belajar sambil bekerja. Secara singkat, PLA adalah metode pemberdayaan 
masyarakat yang terdiri dari proses belajar (melalui ceramah, diskusi, dll) tentang sesuatu topik pemberdayaan yang setelah itu diikuti dengan aksi atau kegiata riil yang relevan dengan materi pemberdayaan masyarakat tersebut. (e) SL (Sekolah Lapangan) merupakan kegiatan pertemuan berkala yang dilakukan oleh sekelompok masyarakat pada hamparan tertentu yang diawali dengan membahas masalah yang sedang dihadapi, kemudian diikuti dengan curah pendapat dan sharing. Metode SL ini biasanya difasilitasi oleh fasilitator atau narasumber yan berkompeten. (f) Pelatihan Partisipatif, metode ini dirancang sebagai implementasi metode pendidikan orang dewasa dengan ciri utama hubungan instruktur/ fasilitator dengan peserta didik lebih bersifat lateral/horizontal serta lebih mengutamakan proses dari pada hasil, dalam arti keberhasilan pelatihan tidak diukur dari seberapa banyak terjadi alih pengetahuan,tetapi seberapa jauh terjadi interaksi atau diskusi dan berbagi pengalaman (sharing) antara sesama peserta maupun antara fasilitator dengan pesertanya. Penelitian ini menggunakan metode pemberdayaan PLA (Participatory Learning and Action) atau Proses Belajar dan Praktik secara Partisipatif dengan dipadukan metode Tatap Muka untuk diterapkan dalam pemberdayaan perempuan penjual Tabaro Dange karena peneliti menilai metode ini lebih tepat dengan kondisi mereka dalam ruang lingkup pemberdayaan sektor usaha kecil.

\section{Strategi Pemberdayaan Masyarakat}

Pemberdayaan ditujukan untuk mengubah perilaku masyarakat agar mampu berdaya sehingga ia dapat peningkatan kualitas hidup dan kesejahteraan. Menurut Suharto dalam Anwas (2013:87) penerapan pendekatan pemberdayaan dapat dilakukan melalui 5P yaitu pemungkinan, penguatan, perlindungan, penyokongan dan dan pemeliharaan. Kegiatan pemberdayaan masyarakat merupakan suatu kegiatan yang memiliki tujuan yang jelas dan harus dicapai, oleh sebab itu, setiap pelaksanaan pemberdayaan masyarakat perlu dilandasi dengan strategi pemberdayaan yang tepat demi keberhasilan dan pencapaian tujuan.

Dalam penelitian ini,peneliti mengadopsi strategi pemberdayaan perempuan yang diaplikasikan kepada usaha penjualan tabaro dange adalah metode yang dikemukakan oleh Mardikanto dan Soebiato (2013:169) yaitu sebagai berikut. (a) Menyusun instrumen pengumpulan data. Dalam kegiatan ini, informasi yang diperlukan didapatkan melalui hasil-hasil penelitian terdahulu, referensi yang ada dan dari hasil temuan pengamatan di lapangan. (b) Membangun pemahaman, komitmen untuk mendorong kemandirian individu, keluarga dan masyarakat. (c) Mempersiapkan sistem informasi, mengembangkan sistem analisis. Intervensi, monitoring dan evaluasi pemberdayaan individu, keluarga dan masyarakat.

\section{Pengertian Usaha}

Usaha atau dapat juga disebut suatu perusahaan adalah suatu bentuk usaha yang melakukan kegiatan secara tetap dan terus menerus dengan tujuan 
memperoleh keuntungan, baik yang diselenggarakan oleh perorangan maupun badan usaha yang berbentuk badan hukum atau tidak berbentuk badan hukum, yang didirikan dan berkedudukan di suatu daerah dalam suatu negara. Usaha juga dapat diartikan sebagai segala kegiatan ekonomi yang dilakukan oleh manusia dalam rangka mencapai tujuan tertentu. Usaha dapat di bagi menjadi usaha kecil, usaha menengah, usaha kecil menengah dan usaha besar. Dalam penelitian ini diprioritaskan pada usaha kecil. Usaha kecil adalah usaha yang membuat produk khusus, unik dan spesial agar tidak bersaing dengan usaha besar, daerah pemasaran dari usaha kecil tidak terlalu luas sehingga konsumennya dapat betulbetul dikuasai dan dengan modal yang terbatas usaha kecil yang sukses bersifat luwes dan sering menghasilkan inovasi-inovasi. Dengan ukuran yang kecil sering mengabaikan prinsip operasi usaha, akibatnya kebijakan usaha dibuat berdasarkan perkiraan, kebiasaan dan naluri.

Usaha kecil merupakan kekuatan ekonomi kerakyatan yang tangguh. Membangun usaha kecil berarti membangun ekonomi masyarakat banyak. Menurut Kartasasmita dalam Anwas (2013: 124), ekonomi rakyat adalah ekonomi masyarakat lapisan bawah yang bersifat tradisional, skala usaha kecil dan bersifat sekedar survive untuk mempertahankan hidup. Secara umum usaha kecil memiliki karakteristik sebagai usaha yang tergolong ekonomi lemah, baik dari aspek pengetahuan, keterampilan,teknologi yang digunakan, permodalan, pemasaran, promosi dan juga kerjasama masih rendah. Kelompok usaha ini sulit bersaing dengan perusahaan raksasa. Oleh karena itu usaha kecil ini perlu diberdayakan untuk dapat survive dan mandiri.

Menurut Anwas (2013:124-125), upaya untuk memberdayakan usaha kecil dimulai dari analisis kebutuhan dan masalah yang dihadapi serta potensi yang bisa dikembangkan oleh para pengusaha kecil tersebut. Apakah usahanya memiliki keunggulan atau kekhasan yang bisa daya tarik diferensiasi bagi produk kompetitif lainnya. Pengembangan usaha kecil juga perlu diperhatikan potensi lokal dan kearifan-kearifan lokal. Hal ini jika dipertahankan justru akan menjadi nilai kekhasan dan mennjadi daya tarik serta memiliki nilai jual tinggi. Berdasarkan penjelasan diatas maka usaha kecil yang diteliti dalam penelitian ini yaitu usaha ibu-ibu penjual Tabaro Dange di sepanjang kawasan Pantai Teluk Kota Palu.

\section{Tabaro Dange}

Tabaro Dange adalah penganan khas masyarakat Sulawesi Tengah yang terbuat dari olahan sagu yang dicampur dengan parutan kelapa. Menurut Kamus Kaili Ledo-Indonesia-Inggris (2012:35), Tabaro adalah sagu sedangkan Dange (Nodange) adalah menggoreng tanpa menggunakan minyak dengan menggunakan wajan yang terbuat dari tanah liat. Proses pembuatan Tabaro Dange disepanjang kawasan kuliner pantai teluk Palu tergolong masih tradisional serta masih mempertahankan kearifan lokal dalam mengolah penganan tersebut yaitu hanya 
menggunakan tungku dan juga tanah liat. Sehingga menciptakan daya tarik sendiri bagi pembeli ketika menyaksikan secara langsung proses pembuatannya. Pengolahan penganan ini secara tradisional juga dipercaya dapat menjaga kualitas rasa dari Tabaro Dange tersebut.

Biasanya Tabaro Dange diberi isian gula merah atau ikan di dalamnya. Tapi tak sedikit juga masyarakat Kota Palu yang menyukai Tabaro Dange tanpa isian sehingga rasanya masih original. Cita rasa makanan tradisional ini sangat khas dengan wangi yang dihasilkan oleh campuran sagu serta kelapa. Tabaro Dange sangat nikmat disantap ketika masih panas karena akan terasa renyah pada bagian luarnya. Proses pembuatan makanan ini pertama-tama sagu dan kelapa dicampurkan lalu diberi sedikit garam agar terasa gurih. Setelah dicampur adonan dimasak di atas belanga atau wajan yang terbuat dari tanah liat. Adonan Tabaro Dange dimasak di atas panasnya tungku yang masih menggunakan kayu bakar. Selanjutnya adonan Tabaro Dange diberi isian ikan atau gula merah lalu dilipat menjadi dua bagian lalu Tabaro Dange siap disantap.

Tabaro Dange kini mulai dijual di beberapa sudut Kota Palu, seperti di sepanjang kawasan kuliner pantai teluk Palu (Taman Ria, sepanjang Jalan Cumi-cumi dan jalan Cut Meutia). Deretan ibu-ibu dengan tungku dan belanganya mulai terlihat ramai di pinggir jalan di kala sore datang. Ini menjadi pemandangan unik dan khas saat berjalan-jalan di Kota Palu. Tabaro Dange ini dibuat langsung di tempat, sehingga pembeli bisa melihat langsung proses pembuatan dari awal hingga akhirnya siap disantap. Para ibu-ibu penjual itu mulai berjualan sekitar pukul 15.00 WITA. Biasanya Tabaro Dange dengan isian gula merah dijual seharga Rp5.000. Sementara untuk isian tumis tuna suwir, dijual seharga Rp5.000.

\section{Penelitian Terdahulu}

Rohmah (2014) dengan judul "Model Pemberdayaan Ekonomi Perempuan Melalui Grassroot Microfinance Syariah". Penelitian ini bertujuan untuk menganilasa model pemberdayaan ekonomi perempuan di DPU Tauhid Daarut dan pengaruhnya dalam meningkatkan pendapatan keluarga. Bariyah (2012) dengan judul "Kontekstualisasi Total Quality Management dalam Lembaga Pengelola Zakat untuk Pemberdayaan Ekonomi Masyarakat (Prinsip dan Praktik)". Disertasi ini menunjukkan bahwa lembaga pengelola zakat harus menerapkan manajemen mutu dalam upaya memberdayakan ekonomi masyarakat. Indikator manajemen mutu kinerja lembaga pengelola zakat meliputi: Kepemimpinan, Perencanaan Strategis, Fokus pada Pengelolaan Muzaki dan Mustahik, Pengukuran, Analisis dan Manajemen Pengetahuan, Sumber Daya Amil, dan Pencapaian Hasil. Lembaga pengelola zakat harus memegang teguh prinsip syari'ah dalam mewujudkan nilai-nilai keadilan distributif untuk memelihara aqidah ( $h$ \}ifz\} al-din ), memelihara harta ( $h$ \}ifz al-mal), memelihara keturunan (h\}ifz\} al-nasl), memelihara jiwa (hlifz\} al-nafs) dan memelihara akal (h)ifz\} al-'aql) para mustahik. 
Sarpeni \& Sari (2011) dengan judul "Upaya Pemberdayaan Ekonomi Perempuan melalui Pengembangan Manajemen Usaha Kecil (Studi Deskriptif pada Kegiatan Usaha Kecil Ibu-Ibu Desa Wirolegi Kabupaten Jember, Dampingan Pusat Studi Wanita UM Jember)". Tujuan penelitian ini adalah untuk menyusun rancangan sederhana pengembangan manajemen usaha kecil yang berkelanjutan dan mudah diaplikasikan bagi perempuan desa. Dari ketiga penelitian tersebut maka, pada penelitian ini berusaha mengembangkan penelitian yang dilakukan oleh Sarpeni \& Sari (2011) dengan tujuan menyusun rancangan sederhana pengembangan manajemen usaha kecil yang berkelanjutan dan mudah diaplikasikan sedangkan penelitian ini bertujuan mewujudkan metode dan srategi pemberdayaan yang mudah diaplikasikan melalui usaha penjualan Tabaro Dange di sepanjang Kawasan Kuliner Pantai Teluk Palu serta mengetahui dampak usaha penjualan Tabaro Dange di sepanjang Kawasan Kuliner Pantai Teluk Palu terhadap peningkatan perekonomian ibu-ibu penjual Tabaro Dange

\section{Kerangka Konseptual}

Berikut gambar model kerangka konseptual dari penelitian ini adalah sebagai berikut.

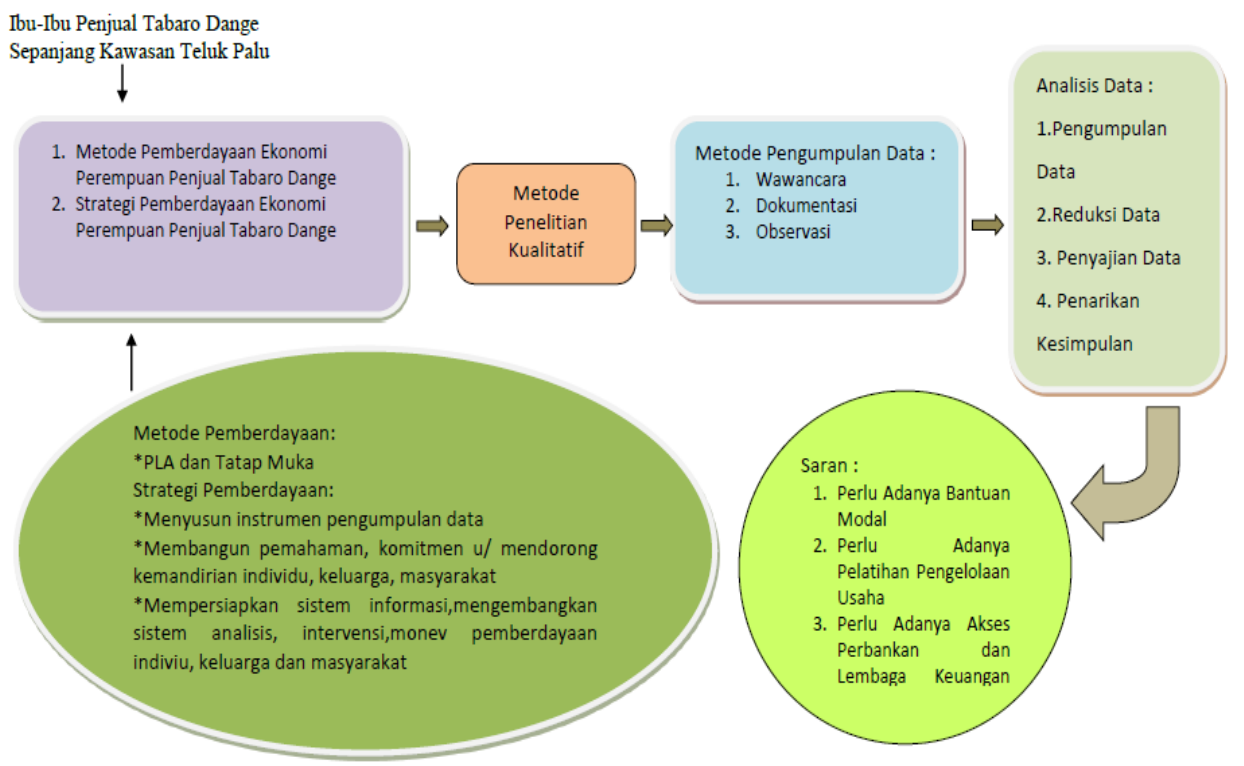

Sumber: diolah penulis

Gambar 1 Kerangka Konsptual

\section{METODE PENELITIAN}

\section{Jenis Penelitian}

Penelitian ini menggunakan pendekatan kualitatif atau naturalistic dengan paradigma konstruktifisme yang memandang manusia sebagai orang yang aktif menciptakan kehidupan sosialnya sendiri, tidak memandang individu yang statis dan terpaksa dalam bertindak. Menurut Bogdan dan Taylor (2010:3) penelitian kualitatif adalah prosedur penelitian yang berupa kata-kata tertulis atau lisan dari 
orang-orang dan perilaku yang dapat diamati. Adapun sifat penelitan ini adalah merupakan penelitian dekriptif analitis kritis, yaitu suatu penelitian yang berupaya untuk menggambarkan secara rinci fenomena sosial yang menjadi pokok permasalahan tanpa melakukan hipotesa dan perhitungan secara statistik. Metode pengumpulan data yang digunakan adalah metode survey untuk memperoleh data primer secara langsung dari sumber asli. Metode ini merupakan metode pengumpulan data primer yang menggunakan pertanyaan atau pernyataan tertulis dan lisan yang memerlukan adanya kontak atau hubungan antara peneliti dengan subjek (responden) untuk memperoleh data yang diinginkan.

\section{Lokasi Penelitian}

Penelitian ini dilaksanakan di kawasan sepanjang pantai teluk Kota Palu (Taman Ria, jalan Cumi-Cumi, dan jalan Cut Meutia), dengan alasan lokasi penelitian yang sangat strategis dan mudah dijangkau untuk melakukan observasi penelitian lebih mendalam terhadap usaha penjualan Tabaro Dange disepanjang Kawasan Kuliner Pantai Teluk Palu

\section{Subyek dan Obyek Penelitian}

Menurut Moleong (2011:248), subyek penelitian adalah orang pada latar penelitian. Dengan kata lain subyek penelitian adalah orang yang dimanfaatkan untuk memberikan informasi tentang situasi dan kondisi latar penelitian. Oleh karena itu, untuk menentukan atau memilih subyek penelitian yang baik harus dengan orang yang sudah lama dan intensif menyatu dalam kegiatan kajian penelitian, terlibat langsung dan mempunyai waktu yang cukup untuk dimintai keterangan. Sehingga yang menjadi subyek penelitiannya adalah ibu-ibu penjual Tabaro Dange disepanjang kawasan kuliner pantai teluk Palu. Wawancara dan observasi dilakukan langsung kepada ibu-ibu penjual Tabaro Dange untuk mendapatkan data mengenai proses pembuatan Tabaro Dange dalam pemberdayaan ekonomi perempuan Obyek penelitian yaitu pokok bahasan dari penelitian yang akan dilakukan oleh penulis. Obyek dalam penelitian ini adalah pemberdayaan ekonomi perempuan melalui usaha penjualan Tabaro Dange.

\section{Tehnik Pengumpulan Data}

Teknik pengumpulan data yang digunakan dalam penelitian ini adalah wawancara, observasi dan dokumentasi. (a) Metode Wawancara atau Interview, wawancara adalah proses memperoleh keterangan untuk tujuan penelitian dengan cara tanya jawab, sambil bertatap muka antara pewawancara sebagai pemberi pertanyaan dengan yang diwawancara atau terhadap subyek penelitian mengenai pemberdayaan perempuan melalui usaha penjualan tabaro dange. (b) Metode Dokumentasi, dokumentasi adalah catatan peristiwa yang sudah berlalu. Dokumen bisa berbentuk tulisan atau karya-karya monumental dari seseorang. Dokumen yang berbentuk tulisan misalnya, catatan harian, sejarah kehidupan sedangkan 
dokumen yang berbentuk gambar seperti foto. Peneliti mengumpulkan data-data untuk melengkapi penelitian yaitu dengan membaca dan mencatat data. Selain itu peneliti juga mengumpulkan data lainnya yang diperoleh dari usaha penjualan Tabaro Dange, seperti foto saat membuat Tabaro Dange berlangsung. (c) Metode Observasi, observasi adalah teknik pengumpulan data melalui pengamatan langsung dan pencatatan sistematis fenomena-fenomena yang diselidiki yang dilakukan secara langsung maupun tidak langsung. Adapun observasi yang digunakan dalam penelitian ini observasi nonpartisipan, artinya peneliti dalam pengamatannya terhadap obyek penelitian terlibat langsung, agar dapat mengetahui lebih jelas data tentang hal yang berkaitan dengan apa yang sedang diteliti. Dalam observasi ini peneliti mengamati secara langsung, mencatat, menganalisa dan selanjutnya membuat kesimpulan tentang bagaimana proses pemberdayaan ekonomi perempuan yang dilakukan oleh ibu-ibu penjual Tabaro Dange dikawasan wisata kuliner sepanjang pantai teluk Kota Palu. Hal ini dilakukan guna mendapatkan informasi yang relevan dengan topik penelitian.

\section{Teknik Validitas Data}

Banyak hasil penelitian kualitatif diragukan kebenarannya, subjektifitas penelitian merupakan hal yang dominan dalam penelitian kualitatif, alat penelitian yang digunakan adalah wawancara dan observasi mengandung banyak kelemahan ketika dilakukan secara terbuka dan tanpa kontrol serta sumber data kualitatif yang kurang credible akan mempengaruhi hasil akurasi penelitian. Oleh karena itu, dibutuhkan kredibilitas atau tingkat kepercayaan untuk menentukan kevaliditan data. Cara memperoleh kredibilitas atau tingkat kepercayaan dalam penelitian adalah dengan memperpanjang waktu tinggal dengan yang diteliti, observasi secara tekun, dan menguji data dengan triangulasi. Sedangkan triangulasi yang digunakan dalam penelitian ini adalah triangulasi sumber, metode dan teori yaitu: (a) Membandingkan data pengamatan dengan data hasil wawancara. (b) Membandingkan hasil wawancara dengan dokumentas. (c) Membandingkan hasil dokumentasi dengan pengamatan

\section{Analisis Data}

Dalam penelitian ini metode yang akan digunakan adalah analisis data model Miller dan Hubermant, yang terkenal dengan model analisis interaktif yang terdiri dari: a) pengumpulan data yaitu dilakukan dengan terjun ke lapangan (data yang diperoleh berupa data hasil wawancara, observasi dan dokumentasi); b) reduksi, yaitu sebuah proses analisis, untuk mengelola kembali data yang masih kasar yang diperoleh dari lapangan. Data kasar tersebut kemudian dipilah dan digolongkan antara yang penting dan tidak penting. Bagian yang tidak perlu kemudian dibuang; c) penyajian data merupakan bentuk rancangan informasi dari hasil penelitian di lapangan yang tersusun dan mudah dipahami; d) penarikan 
kesimpulan, pada tahap ini penarikan kesimpulan dilakukan pengukuran alur sebab akibat dan menentukan kategori-kategori hasil penelitian.

\section{HASIL DAN PEMBAHASAN}

Data penelitian ini diperoleh dari wawancara dengan para informan yaitu ibu-ibu penjual tabaro dange sepanjang kawasan teluk pantai talise. Adapun hasil yang didapatkan yaitu: Metode pemberdayaan ekonomi perempuan yang bisa diaplikasikan melalui usaha penjualan Tabaro Dange di sepanjang Kawasan Kuliner Pantai Teluk Palu. Dipenjelasan sebelumnya telah dijelaskan bahwa dalam penelitian ini mengaplikasikan perpaduan metode pemberdayaan PLA (sharing dan diskusi mengenai pemberdayaan ekonomi perempuan melalui usaha penjualan tabaro dange) dan Tatap Muka, dimana metode ini dianggap paling menyesuaikan dengan kondisi informan. Metode ini dikenal juga dengan metode "learning by doing" atau belajar sambil bekerja, jadi pelaksanaannya di lapangan peneliti melakukan sharing dan diskusi sambil si informan melayani penjualan tabaro dange sehingga lebih efisiensi dan efektif serta tidak mengganggu aktivitas informan tersebut.

Melalui hasil sharing dan diskusi tersebut didapatkan bahwa dari usaha penjualan tabaro dange, ibu-ibu tersebut bisa survive dengan pengelolaan usaha yang masih konvensional. Walaupun pengelolaan keuangan dari usaha tersebut masih sangat sederhana bahkan dari sebagian ibu-ibu tersebut masih belum bisa memisahkan antara keuangan usaha dengan keuangan pribadi. Kondisi ini diperparah dengan tidak adanya pencatatan transaksi keuangan sehingga perputaran modal usaha menjadi tidak jelas dan tidak terkontrol. Sebagaimana yang disampaikan oleh Bu Sumarni: "Modal saya untuk penjualan tabaro dange untuk satu hari dari penjualan, untungnya saya gunakan untuk belanja sehari-hari dan saya tidak pernah melakukan pencatatan hasil usaha setiap harinya" (Mei, 2018). Pola yang demikian menyebabkan usaha ibu-ibu tersebut menjadi stagnan. Walaupun demikian dapat dikatakan bahwa partisipasi perempuan dari ibu-ibu penjual tabaro dange sudah mengalami peningkatan dalam rumah tangga meskipun belum optimal sehingga perlu adanya tindak lanjut sesuai kebutuhan mereka, seperti akses untuk mendapatkan pelatihan dan pendampingan untuk meningkatkan penghasilan dari penjualan tabaro dange atau pelatihan dan pendampingan pembukuan sederhana.

Dari segi produksi, pembuatan tabaro dange masih mempertahankan kearifan lokal. Proses pembuatan Tabaro Dange disepanjang kawasan kuliner pantai teluk Palu tergolong masih tradisional serta masih mempertahankan kearifan lokal dalam mengolah penganan tersebut yaitu hanya menggunakan tungku dan juga tanah liat. Sehingga menciptakan daya tarik sendiri bagi pembeli ketika menyaksikan secara langsung proses pembuatannya. Pengolahan penganan ini secara tradisional juga dipercaya dapat menjaga kualitas rasa dari Tabaro 
Dange tersebut. Disisi lain harga jual yang masih rendah dan tidak dibarengi dengan daya beli masyarakat yang maksimal membuat usaha penjualan taboro ini lambat berkembang. Hal ini sejalan dengan kreatifitas ibu-ibu tersebut yang masih terbatas dalam menciptakan inovasi varian rasa dan topping untuk tabaro dange yang dijual. Hal ini diungkapkan oleh salah satu informan: "tabaro dange yang banyak dipesan oleh pembeli adalah tabaro dange isi gula merah, nike dan ikan tuna suwir, untuk isian lainnya kami masih belum mencoba dikarenakan akan menghilangkan cita rasa asli dari tabaro dange dan kami tidak berani untuk memberi isian lainnya karena rasanya belum tentu pas dilidah pembeli. Tabaro dange isi gula merah, nike dan ikan tuna suwir sesuai dengan lidah orang tua kita dari zaman dahulu sampai sekarang" (Ibu Sarulia, Mei 2018).

Penjelasan dari segi produksi di atas menunjukkan kualitas sumber daya manusia yang dimiliki oleh ibu-ibu penjual tabaro dange masih rendah sehingga kemampuan untuk melakukan inovasi olahan tabaro dange perlu suatu pelatihan dan pendampingan. Tak dapat dipungkiri hal ini berimbas pada lingkup pemasaran hasil jualan yang masih terbatas di lingkungannya sendiri yaitu di kawasan teluk pantai talise. Strategi pemberdayaan ekonomi perempuan yang bisa diaplikasikan melalui usaha penjualan Tabaro Dange di sepanjang Kawasan Kuliner Pantai Teluk Palu. Strategi pemberdayaan perempuan yang diaplikasikan kepada usaha penjualan tabaro dange yang dilakukan oleh peneliti adalah yang dikemukakan oleh Mardikanto dan Soebiato (2013:169) yaitu:

\section{Menyusun Instrumen Pengumpulan Data}

Dalam kegiatan ini, peneliti mendapatkan informasi yang diperlukan melalui hasil-hasil penelitian terdahulu, referensi yang ada dan dari hasil temuan pengamatan di lapangan. Adapun hasil temuan pengamatan dan observasi di lapangan bahwa ibu-ibu penjual tabaro dange disepanjang kawasan pantai talise belum memiliki kelompok usaha, mereka masih berjualan dengan modal sendirisendiri walaupun demikian interaksi sesama penjual cukup dekat, kearifan lokal Nosara Nosabatutu masih tertanam dalam diri mereka. Nosarara Nosabatutu adalah semboyan dalam dialek Kaili (bahasa suku kaili), salah satu suku yang ada di wilayah Kota Palu. Nosarara Nosabatutu yang berarti bersama kita satu. Itulah gambaran kebersamaan untuk mencapai tujuan keberhasilan. Hal ini biasa terjadi apabila salah satu dari mereka kekurangan bahan baku untuk proses produksi tabaro dange sedangkan masih ada permintaan dari pembeli. Penjual yang masih memiliki sisa bahan sagu atau isian ikan tuna suwir dengan sukarela akan memberikannya kepada salah satu penjual yang membutuhkan.

Tradisi memegang budaya kearifan lokal Nosarara Nosabatutu ini menunjukkan pemberdayaan tidak bermaksud membekali perempuan dengan kekuasaan dan kekayaan tetapi membuat mereka sadar terhadap dirinya, dan apa yang diinginkannya dari hidup ini. Proses pemberdayaan memungkinkan manusia dihadapkan pada berbagai pilihan. Sehingga pemberdayaan psikologi 
mengandung makna saling menghormati dan menghargai serta tolong menolong, bukan saja dalam hal apa yang dilakukan masing-masing tetapi juga sebagai insan manusia dan apa yang menjadi pilihan-pilihan hidup. Usaha penjualan tabaro dange ini harusnya menunjukkan pentingnya perempuan untuk mempunyai penghasilan sendiri. Yang memungkinkan baginya untuk mengatur dan mengontrol masalah keuangannya sendiri walaupun dalam kenyataannya mereka belum mampu membuat pembukuan sederhana karena belum tersentuh pelatihan dan pendampingan. Akan tetapi, perlu diperhatikan bahwa tidak semua perempuan memasuki lapangan pekerjaan dengan tujuan memperkaya dirinya sendiri secara ekonomis, misalnya dalam hal melakukan aktualisasi atau pengembangan diri. Dan dalam kenyataannya, perempuan mencari kerja untuk tujuan meringankan beban pengeluaran keluarga (rumah tangga), membiayai pendidikan dan keperluan keluarganya. Disisi lain perempuan memilih bekerja bukan semata-mata tuntunan ekonomi akan tetapi karena ingin memuaskan kebutuhan pribadinya.

Belum ada atau terbentuknya kelompok usaha bagi mereka menunjukkan akses ibu-ibu penjual tabaro dange masih begitu kurang. Akses dalam hal ini dapat diartikan sebagai kemampuan perempuan untuk dapat memperoleh hak terhadap sumber daya produktif seperti kredit, pelatihan, fasilitas pemasaran dan semua pelayanan publik yang setara dengan perempuan. Selain itu, akses terhadap teknologi dan informasi juga sangat penting. Ibu-ibu penjual tabaro dange dapat meningkatkan produktivitas ekonomi dan sosial mereka melalui teknologi dan informasi. Tanpa akses-akses di atas, pemahaman serta kemampuan untuk menggunakan teknologi informasi, ibu-ibu penjual tabaro dange akan jauh lebih termarjinalisasi dari komunitas lingkungannya.

\section{Membangun Pemahaman, Komitmen untuk Mendorong Kemandirian Individu, Keluarga dan Masyarakat}

Pemberdayaan perempuan dibidang ekonomi kreatif keluarga dilaksanakan melalui penumbuhan minat dan motivasi di bidang usaha dengan proses pembelajaran yang terarah dan berkelanjutan melalui pendekatan kelompok. Upaya pemberdayaan dengan pendekatan kelompok ini diharapkan perempuan mampu mengembangkan potensinya dalam memanfaatkan berbagai bantuan dan peluang yang ada. Dengan menjadi anggota kelompok diharapkan akan timbul rasa kebersamaan yang dapat mendorong proses belajar, pemecahan masalah serta mobilisasi sumber daya diantara anggota kelompok.

Mengacu pada kondisi perempuan dalam bidang ekonomi dimana akses terhadap sumber daya ekonomi yang ada pada kenyataannya masih rendah dan mempertahankan potensi yang dapat dikembangkan maka perlu dikoordinasikan beberapa hal yaitu perlunya memberikan kesempatan pada perempuan yang mempunyai potensi baik dalam kelompok maupun perseorangan dalam 
meningkatkan pemberdayaan perempuan melalui usaha ekonomi produktif (Prantiasih,2014:4).

Fakta kondisi di lapangan bahwa belum adanya kelompok usaha bagi ibuibu penjual tabaro dange, sehingga akses untuk mendapatkan bantuan modal usaha dari perbankan dan lembaga keuangan lainnya sangat kecil. Hal ini ditambah dengan belum adanya andil pemerintah setempat melalui dinas terkait untuk memberdayakan ibu-ibu penjual tabaro dange dalam meningkatkan pendapatan, memberikan pelatihan ataupun bantuan modal. Di sisi lain, perempuan memiliki peran ganda. Disatu sisi sebagai tenaga kerja yang menerima upah atau memproduksi dan disisi lain sebagai ibu rumah tangga. Masih terbatasnya ruang gerak perempuan tidak menjadi penghalang bagi ibu-ibu penjual tabaro dange ini dalam mencari nafkah. Hasil observasi peneliti di lapangan, sebagian besar domisili ibu-ibu penjual tabaro dange ini berasal dari Desa Kola-Kola, Kabupaten Donggala. Mereka menuju lokasi penjualan dari jam 14.00 WITA dan sampai di kawasan pantai teluk Talise sekita pukul 15.00 WITA dan langsung menggelar jajanannya kepada pembeli. Kegiatan menjual tabaro dange ini dilakukan kadang sampai pukul 24.00 WITA bila sedang ramai oleh pengunjung. Sehingga dalam sehari waktu yang mereka gunakan untuk mencari nafkah dengan berjualan tabaro dange lebih dari 10 jam.

Dari penjelasan di atas, waktu yang mereka lakukan untuk berperan sebagai ibu rumah tangga adalah 14 jam. Sehingga secara tidak langsung usaha penjualan tabaro dange yang mereka lakoni selama ini berpotensi meningkatkan posisi tawar (bargaining position) perempuan dalam keluarga. Usaha penjualan tabaro dange ini masuk dalam klasifikasi kegiatan usaha kecil atau mikro yang tidak lepas dari peran kaum perempuan. Sehingga hasil pembahasan ini sejalan dengan apa yang dikatakan oleh Sumampouw (2000) dalam Supeni dan Sari (2011:106) bahwa usaha kecil atau mikro banyak diminati oleh perempuan dengan pertimbangan bahwa usaha ini dapat menopang kehidupan rumah tangga dan dapat memenuhi kebutuhan pengembangan diri.

\section{Mempersiapkan Sistem Informasi, Mengembangkan Sistem Analisis, Intervensi, Monitoring Dan Evaluasi Pemberdayaan Individu, Keluarga dan Masyarakat}

Dari penjelasan di atas, secara garis besar persiapan sistem informasi, mengembangkan sistem analisis, intervensi, monitoring dan evaluasi pemberdayaan ibu-ibu penjual tabaro dange meliputi beberapa aspek, yaitu sebagai berikut. (a) Aspek Keuangan. Pengelolaan keuangan yang dilakukan oleh ibu-ibu penjual tabaro dange masih sangat sederhana bahkan mereka belum bisa memisahkan antara keuangan usaha dengan keuangan pribadi. Kondisi di lapangan tidak ada pencatatan transaksi keuangan sehingga perputaran modal usaha tidak jelas dan tidak terkontrol. Pernyataan oleh salah satu informan yaitu ibu Hawalia (Juli, 2018) bahwa penghasilan yang didapat oleh ibu-ibu penjual 
tabaro dange tersebut berkisaran $\mathrm{Rp} 150.000$,- per hari dikurangi biaya transportasi pulang pergi dari Desa Kola-Kola - Palu atau sebaliknya sebesar Rp.40.000,- sehingga total penghasilan mereka dalam sehari adalah Rp.110.000,-. Peningkatan pendapatan ini bisa ditingkatkan dengan mendapatkan akses dari bank dan lembaga keuangan untuk bisa mendapatka bantuan modal. (b) Aspek Produksi/ Operasional dan Pemasaran. Kualitas sumber daya manusia yang dimiliki oleh ibu-ibu penjual tabaro dange masih rendah sehingga kemampuan untuk melakukan inovasi olahan tabaro dange perlu suatu pelatihan dan pendampingan. Tak dapat dipungkiri hal ini berimbas pada lingkup pemasaran hasil jualan yang masih terbatas di lingkungannya sendiri yaitu di kawasan teluk pantai talise. Disisi lain proses produksi dan pemasaran tabaro dange ini belum tersentuh teknologi untuk pengembangan usaha tetapi masih mengandalkan cara traditional. (c) Aspek Sumber Daya Manusia. Kualitas SDM dari ibu-ibu penjual tabaro dange ini masih tergolong rendah karena latar belakang pendidikannya tetapi mereka memiliki keterampilan dalam mengolah suatu penganan yang terbuat dari sagu menjadi tabaro dange. Karena minimnya kualitas pendidikan yang mereka miliki sudah selayaknya mereka mendapatkan pelatihan dan pendampingan dari pemerintah ataupun lembaga social sehingga mereka bisa membentuk suatu kelompok usaha bersama (KUBE) sehingga ke depannya mereka mudah mendapatkan modal dari lembaga keuangan.

\section{KESIMPULAN}

Metode pemberdayaan ekonomi perempuan yang bisa diaplikasikan melalui usaha penjualan Tabaro Dange di sepanjang Kawasan Kuliner Pantai Teluk Palu adalah perpaduan metode pemberdayaan PLA (sharing dan diskusi mengenai pemberdayaan ekonomi perempuan melalui usaha penjualan tabaro dange) dan Tatap Muka, dimana metode ini dianggap paling menyesuaikan dengan kondisi informan. Metode ini dikenal juga dengan metode learning by doing atau belajar sambil bekerja, jadi pelaksanaannya di lapangan peneliti melakukan sharing dan diskusi sambil si informan melayani penjualan tabaro dange sehingga lebih efisiensi dan efektif serta tidak mengganggu aktivitas informan tersebut.

Strategi pemberdayaan perempuan yang diaplikasikan kepada usaha penjualan tabaro dange yang dilakukan oleh peneliti adalah yang dikemukakan oleh Mardikanto dan Soebiato (2013:169) yaitu sebagai berikut. (a) Menyusun instrumen pengumpulan data. (b) Membangun pemahaman, komitmen untuk mendorong kemandirian individu, keluarga dan masyarakat. (c) Mempersiapkan sistem informasi, mengembangkan sistem analisis, intervensi, monitoring dan evaluasi pemberdayaan individu, keluarga dan masyarakat.

\section{REFERENSI}

Anwas, Oos M. 2013. Pemberdayaan Masyarakat di Era Global. Alfabeta. Bandung. 
Bariyah. 2012. Kontekstualisasi Total Quality Manajemen Dalam Lembaga Pengelola Zakat Untuk Pemberdayaan Ekonomi Masyarakat (Prinsip dan Praktik). Disertasi. Universitas Islam Negeri Syarif Hidayatullah. Jakarta.

Bogdan dan Taylor. 2010. Introduction To Qualitative Research Method. Wiley.

Evans, Donna. 2012. Kamus Kaili-Ledo-Indonesia-Inggris. Dinas Kebudayaa dan Pariwisata Sulawesi Tengah. Cetakan Ketiga. Palu.

Ife, Jim. 2015. Community Development Alternatif: Pengembangan Masyarakat Di Era Globalisasi. Edisi ke 3. Pustaka Pelajar. Yogyakarta.

Mahmud, Thoha. 2009. Kemiskinan Perempuan dan Strategi Survival: Perspektif Ekonomi Syariah Dalam Bunga Rampai Seri Seminar Nasional Memperkuat Kesadaran Gender di Masyarakat. Kalyanamitra. Jakarta.

Mardikanto dan Soebiato. 2013. Pemberdayaan Masyarakat Dalam Perspektif Kebijakan Publik. Alfabeta. Bandung

Mauled, Moelyono. 2010. Menggerakan Ekonomi Kreatif Antara Tuntutan Dan Kebutuhan. Rajawali Pers. Jakarta.

Moleong. 2011. Metodologi Penelitian Kualitatif. Remaja Rosdakarya. Bandung.

Rohmah, Siti. 2014. Model Pemberdayaan Ekonomi Perempuan Melalui Grassroot Microfinance Syariah. SAWWA. Volume 10.

Suharto, Edi. 2010. Membangun Masyarakat Memberdayakan Rakyat: Kajian Strategis Pembangunan Kesejahteraan Sosial dan Pekerjaan Sosial. Refika Aditama.

Sulistiyani, Ambar Teguh. 2004. Kemitraan dan Model-Model Pemberdayaan. Cetakan Pertama. Graha Ilmu. Yogyakarta.

Supeni dan Sari. 2011. Upaya Pemberdayaan Ekonomi Perempuan Melalui Pengembangan Manajemen Usaha Kecil (Studi Deskrptif Pada Kegiatan Usaha Kecil Ibu-Ibu Desa Wirolegi Kabupaten Jember, Dampingan Pusat Studi Wanita UM Jember. Seminar Nasional Ilmu Ekonomi Terapan. Fekon UNIMUS

Prantiasih, Arbiyah. 2014. Reposisi Peran Dan Fungsi Perempuan. Jurnal Pendidikan Pancasila Dan Kewarganegaraan. Th 27 Februari 2014. Nomor 1. 
BISMA (Bisnis dan Manajemen)

Volume 11 Nomor 1, Oktober 2018

E-ISSN 2549-7790, P-ISSN 1979-7192

Halaman 1-19

PariwisataSUMUTnet. 2015. Pengertian Ekonomi Kreatif dan 15 Contoh Industri

Kreatif, https://www.pariwisatasumut.net/2015/01/pengertian-ekonomi-

kreatif-dan-15.html (diakses tanggal 5 Mei 2018) 